\title{
Exploring the potential of edible forest gardens: experiences from a participatory action research project in Sweden
}

\author{
Johanna Björklund $($ D Karin Eksvärd · Christina Schaffer
}

Received: 30 January 2017/ Accepted: 5 February 2018/Published online: 15 February 2018

(C) The Author(s) 2018. This article is an open access publication

\begin{abstract}
To meet the environmental challenges that are presently confronting society, the narrow focus on agricultural production needs to be altered to one that places equal value on the generation of crucial ecosystem services. Current research shows that perennial intercropping systems such as agroforestry may be a feasible alternative. Based on studies during the establishment of edible forest gardens in 12 participating farms in Sweden, this paper explores the potential of utilizing multi-strata designs for food production in temperate, highincome countries. Design and species composition of such gardens, types of food they provide, and how they would best fit into the present landscape are discussed. Factors for success and major problems related to the establishment are shared. Potential benefits were found to be closely related to a thorough analysis of the social and ecological contexts before establishment. Characteristics of the site and goals of the garden need to guide species and
\end{abstract}

\section{J. Björklund ( $\square)$}

School of Science and Technology, Örebro University,

Örebro, Sweden

e-mail: johanna.bjorklund@oru.se

K. Eksvärd

Inspire Action and Research AB, Knivsta, Sweden

C. Schaffer

Department of Physical Geography, Stockholm

University, Stockholm, Sweden design choices. If forest garden approaches to food production should contribute to more than local selfsufficiency, the gardens need to increase in scale. Marginal lands and transitions areas between different land uses may be appropriate. Large knowledge gaps concerning potential production, social and economic benefits, and agronomic issues were identified.

Keywords Agroforestry - Temperate climate . Sustainable food production - Design . Species composition $\cdot$ Multi-strata production

\section{Introduction}

The global food system significantly contributes to the complex and widespread environmental challenges that we face. At present, agriculture plays a serious part by transcending the identified ecological "planetary boundaries" (Steffen et al. 2015), including the four boundaries that are already thought to be exceeded or at high risk of being exceeded: global warming, disruption of the nitrogen cycle, land use changes and extinction of species (Foley 2011). The perpetuating dependency on non-renewable resources, such as phosphorous and fossil fuels, also plays a critical role in planetary health and future food production.

This implies a fundamental renegotiation of the aims of agriculture. The narrow focus on production 
needs to be altered to one that places equal value on the generation of crucial ecosystem services (De Schütter and Vanloqueren 2011). Radical changes in both diets and the modes of production are necessary (Foley 2011). Agroforestry may be a feasible option. Current research shows that such systems are both productive and generate more ecosystem services than conventional land use in tropical and temperate areas (Pretty et al. 2006; Jose 2009; Torralba et al. 2016; Wilson and Lovell 2016).

Agroforestry is defined as "...the integration of woody vegetation, crops and/or livestock on the same area of land" (EURAF 2015) and has also been proposed as a management option for agriculture to meet the challenges related to the planetary boundaries (McIntyre et al. 2009; DeSchütter and Vanloqueren 2011; European Commission 2016). Most of the systems are deliberately designed to use symbiotic interactions within the agroecosystem (Jose 2012). Such systems may involve high levels of planned diversity or intercropping of only two crops (Nair 1993). These designs aim to maximize the benefits by increasing the efficiency of capturing light, water and nutrients (Lorenz and Lal, 2014). The systems can be developed on arable land, in pastures or forests (Nair 1993).

Most experience and knowledge about modern agroforestry has originated from tropical areas (Torralba et al. 2016), where it is a way to increase the production of necessary products when land is a scarce resource (Smith et al. 2012a). However, agroforestry in temperate areas has been a tradition since ancient times. The main agroforestry approach has been silvopastoral systems with livestock grazing in forests or on agricultural land (Herzog 1998; Montagnini and Nair 2004), however, different kinds of silvoarable systems, including nuts, fruits or berries with or without animals, as well as trees and bushes in alleys (e.g., hedgerows and wind breaks), were also common (Herzog 1998; Nerlich et al. 2012). Traditional systems were lost because of competition when low oil prices led to mechanization and intensification (Smith et al. 2012a). Policies based on a division between agriculture and forestry have also not been beneficial (Dupraz et al. 2005). Still, in Europe today, agroforestry is practiced in almost $9 \%$ of the agricultural areas (den Herder et al. 2016).
Meta-analyses from temperate areas present compelling evidence that an increase in the complexity in the agricultural landscape through agroforestry systems delivers more supporting and regulating ecosystem services, such as carbon sequestration, maintenance of biodiversity, water quality, nutrient recycling, soil fertility and erosion, than conventional land use (Tsonkova et al. 2012; Kim et al. 2016; Torralba et al. 2016; Wilson and Lovell 2016).

However, for the systems to be efficient carbon sinks, they must be composed mainly of perennial crops, while this potential is substantially less when perennials are intercropped in systems dominated by annuals (Alam et al. 2014; Torralba et al. 2016). Moreover, the key design components for high conservational values in agroforestry have been found to be the inclusion of multiple species and vegetative strata, minimal management intensity and long rotation periods (Jose 2012).

Edible forest gardens are complex multi-strata agroforests that are characterized by astonishing diversity, including perennial plants at all structural levels, from high trees to low trees, bushes, herbs, soil covers, tubers and climbers (Jacke and Toensmeier 2006). Edible forest gardens have a long tradition among owners of small farms in the southern hemisphere, so called "homegardens", and have been clearly recognized to have social and ecological benefits in tropical areas on all continents (Landreth and Saito 2014; Pulido et al. 2008; Bardhan et al. 2012; Matsson et al. 2015; Willeman et al. 2013). In Europe, these gardens are commonly small-scale systems that contribute to the self-sufficiency of urban or suburban households, with the highest presence in central and eastern Europe (MosqueraLosada et al. 2009).

This paper explores the potential of the multistrata design used in edible forest gardens based on studies during the establishment of edible forest gardens (the first four years) in the agricultural settings of a group of participating farms in Sweden. The design and species composition of such gardens, the kind of food they may provide, and how they would best fit into the present landscape are discussed. The factors for success, major problems in the establishment, working requirements in relation to productive outcome and what the participants valued as the most important benefits from the gardens are shared. Finally, knowledge gaps in the development 
of the multi-strata approach in agriculture are identified.

\section{Materials and methods}

The research presented is based on the knowledge produced and experiences developed within a facilitated participatory action research (PAR) group focusing on the development of modern agroforestry systems in Sweden, 2012-2016. The core of the group comprised farmers from 12 farms, including two researchers and one $\mathrm{PhD}$ student with expertise in environmental science, agroecology and participatory methodologies (Eksvärd et al. 2016). Although all farms are located in the southern parts of Sweden, the climates are notably different (Fig. 1 and Table 1). The sizes of the farms range between 3 and 200 ha. Approximately half of the farmers had experience in agroforestry as silvopastures at the start of the project. The participants consisted of both full- and part-time farmers, and production was for subsistence, commercial reasons or both.

To study the management and use of multi-strata systems, edible forest gardens of $60 \mathrm{~m}^{2}$ with common species compositions and planting schemes were planted in 2013 by the farmers on their farms. The collaboratively developed design contained plants in all structural layers, with species that could exploit the different ecological niches and contribute to a diverse composition of habitats. A theoretical framework of agroecological principles, such as functional design, intentional use of biodiversity, multifunctionality, adapted scale, awareness of ecosystem services, and circulation and effective use of plant nutrients (Gliessman 2014), was used.

During 9 workshops, 15 telephone conferences, and individual work on and in forest gardens, the acquired knowledge and experiences were collectively analyzed and decided upon. Permanent sampling points inside and outside the research site were established during the year of planting. Initial vegetation and basic soil parameters were documented as well as the inputs, outputs and working hours (Tables 1 and 2). Photographic documentation at permanent points on set dates and a diary with notations on important observations were also included. Only seven of the 12 places are included in the summary table (Table 2), as five farmers did not provide enough observations from their sites for inclusion.

\section{Results}

Design and establishment

The desired functions from the systems were agreed to be the provision of nutritious and tasty food products, nitrogen fixation, nutrient accumulation, the provision of quality food for pollinators, carbon sequestration, contribution to a benign microclimate and the provision of timber. The design and species composition were planned to optimize these functions (Fig. 2).

The research gardens were established at different places in the landscape, from farmer fields and permanent pastures to forest slopes and home gardens (Table 2). Some gardens were established in swards, and others on black soil after cultivation with machinery or pigs. In the places with establishment in swards, pits were dug for the plants, and the rest of the area was covered with paper or plastic weave, or, left with the swards. Soil improvements as manure or compost were also added to some of the sites to improve plant establishment. The soil improvements were optional. Some of the farmers chose not to do this to study the potential for self-generation of fertility at these sites.

Experiences on plant composition, development and use

All layers in the three-dimensional structure of the edible forest gardens established on each of the participating farms were dominated by perennial domestic species, with the inclusion of some wild species (e.g., garlic mustard (Alliaria petiolata), fathen (Chenopodium album)). To analyze how the different plants became established and interacted in the design, the Crawford (2010) division of different vertical layers was used:

\section{Medium to large canopy trees $(>10 \mathrm{~m})$}

Experiences from the group suggest that in small or dense and narrow gardens in temperate climates, the first layer of high trees, which provides desirable 


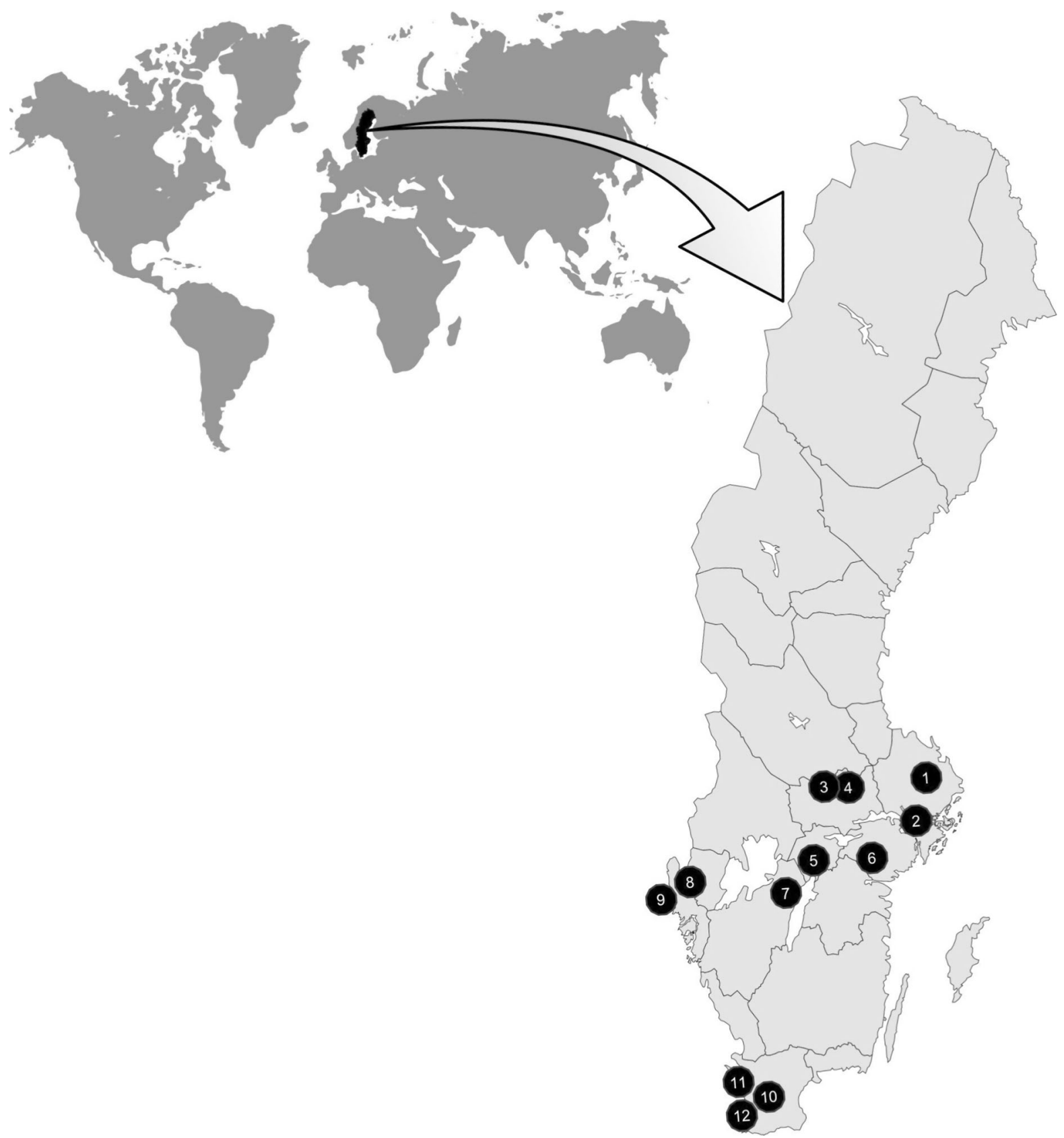

Fig. 1 Map of Sweden showing geographical positions of the edible forest gardens in the study

shade in hot and sunny climates, might not be useful when sunlight is a critical factor in intercropping systems. Especially in locations as Sweden, where the majority of the landscape is used to produce timber. It might be better for the tree layer to be lower, including smaller or coppiced trees that provide edible fruits, berries, leaves and possible nitrogen fixation. In these systems, large trees likely appropriate too much sunlight and space in relation to the services they provide. 
Table 1 Precipitation and temperature during establishment, basic soil parameters before planting and former land use types at the sites

\begin{tabular}{lllllll}
\hline $\begin{array}{l}\text { Farm } \\
\text { number }\end{array}$ & $\begin{array}{l}\text { Average precipitation } \\
\left(\mathrm{mm} \mathrm{year}^{-1}\right)\end{array}$ & $\begin{array}{l}\text { Average annual } \\
\text { temperature }^{\mathrm{a}}\left({ }^{\circ} \mathrm{C}\right)\end{array}$ & Soil & C $(\%)$ & pH & Former land use \\
\hline 1 & 600 & 7.0 & $\mathrm{Cl}$ & 1.79 & 7.8 & Tilled soil \\
2 & 475 & 7.0 & hu Cl & 3.65 & 4.7 & Pasture \\
3 & 800 & 6.5 & $\mathrm{ClTi}$ & 4.61 & 5.2 & Pasture \\
4 & 680 & 6.5 & $\mathrm{cl} \mathrm{Sa}$ & 3.91 & 5.6 & Lawn \\
5 & 665 & 7.5 & hu cl SaTi & 3.45 & 5.3 & Pasture \\
6 & 665 & 7.5 & hu Cl & 5.21 & 7.4 & Pasture \\
7 & 640 & 7.5 & hu Sa & 18.28 & 4.0 & Forest \\
8 & 705 & 9.0 & hu cl SaTi & 9.69 & 4.8 & Forest \\
9 & 765 & 9.0 & hu cl Sa & 6.20 & 7.2 & Lawn \\
10 & 650 & 9.0 & $\mathrm{cl} \mathrm{Ti/cl} \mathrm{Sa}$ & 1.75 & n.a & Lawn \\
11 & 650 & 9.0 & hu cl Ti/hu cl Sa & 6.76 & 4.8 & Pasture \\
12 & 650 & 9.0 & hu cl Ti & 3.95 & n.a & Impediment \\
\hline
\end{tabular}

$\mathrm{Cl}$ clay, $\mathrm{cl}$ clayey, $h u$ humus-bearing, $\mathrm{Ti}$ till, $\mathrm{Sa}$ sand, SaTi sand till, ClTi clay till

a Average 2013-2015 from the nearest Swedish Meteorological and Hydrological Institute (SMHI) weather station

Small trees and large shrubs (4-9 m)

This second layer included three types of apple trees (Malus domestica) to provide fruit over a long period. Hazel (Corylus avellana), a winter-hardy, energydense crop that is traditionally grown, was a selfevident choice. The critical aspects identified by the PAR-group were the selection of large nuts and means for efficient harvest. The sites also included the nitrogen-fixing Siberian pea tree (Caragana arborescens) as a protein source, a common ornamental plant in Sweden. To use the seeds, substantial improvements of the common varieties to obtain larger seeds are necessary. The nutritious value also needs to be further examined.

\section{Shrubs $(<3 m)$}

This level consisted of silverberry (Elaeagnus commutata) (or autumn olive (Elaeagnus umbellata) in the southern sites), the nitrogen-fixing sea buckthorn (Hippophae rhamnoides), saskatoon (Amelanchier alnifolia) and dwarf quince (Chaenomeles japonica). Saskatoon is a common ornamental plant in Swedish urban gardens and was fast growing at most sites while producing tasty berries with high nutritional value (Mazza and Cottrell 2008) that were easy to pick. Furthermore, sea buckthorn exhibited substantial yields only two years after establishment, and dwarf quince was of special interest to the group as a potential substitute for imported citrus.

\section{Herbaceous perennials and evergreen plants $(0-3 \mathrm{~m})$}

This layer contained different kinds of mint (Mentha spp.), mallow (Malva spp.), used in salads or tea, and comfrey (Symphytum uplandica) for its role as a "nutrient pump" from deep layers in the soil because of its extensive root system. Daylilies (Hemerocallis spp.), anise hyssop (Agastache foeniculum), sweet cicely (Myrrhis odorata) and oregano (Origanum vulgare) provided tasty leaves and flowers that could be used in substantial amounts in salads during a large part of the growing season. The PAR group found the fourth layer to be especially important for attracting beneficial insects, birds, and butterflies, acting as soil builders in the early stages, which was verified in master's thesis research performed at five of the research sites (Lagerquist 2016).

Among the herbaceous perennials, good king Henry (Chenopodium bonus-henricus) was perceived to be of special interest. The plant developed fast and provided both leaves to be used in salads and seeds that could be cooked to provide fat and protein. A 


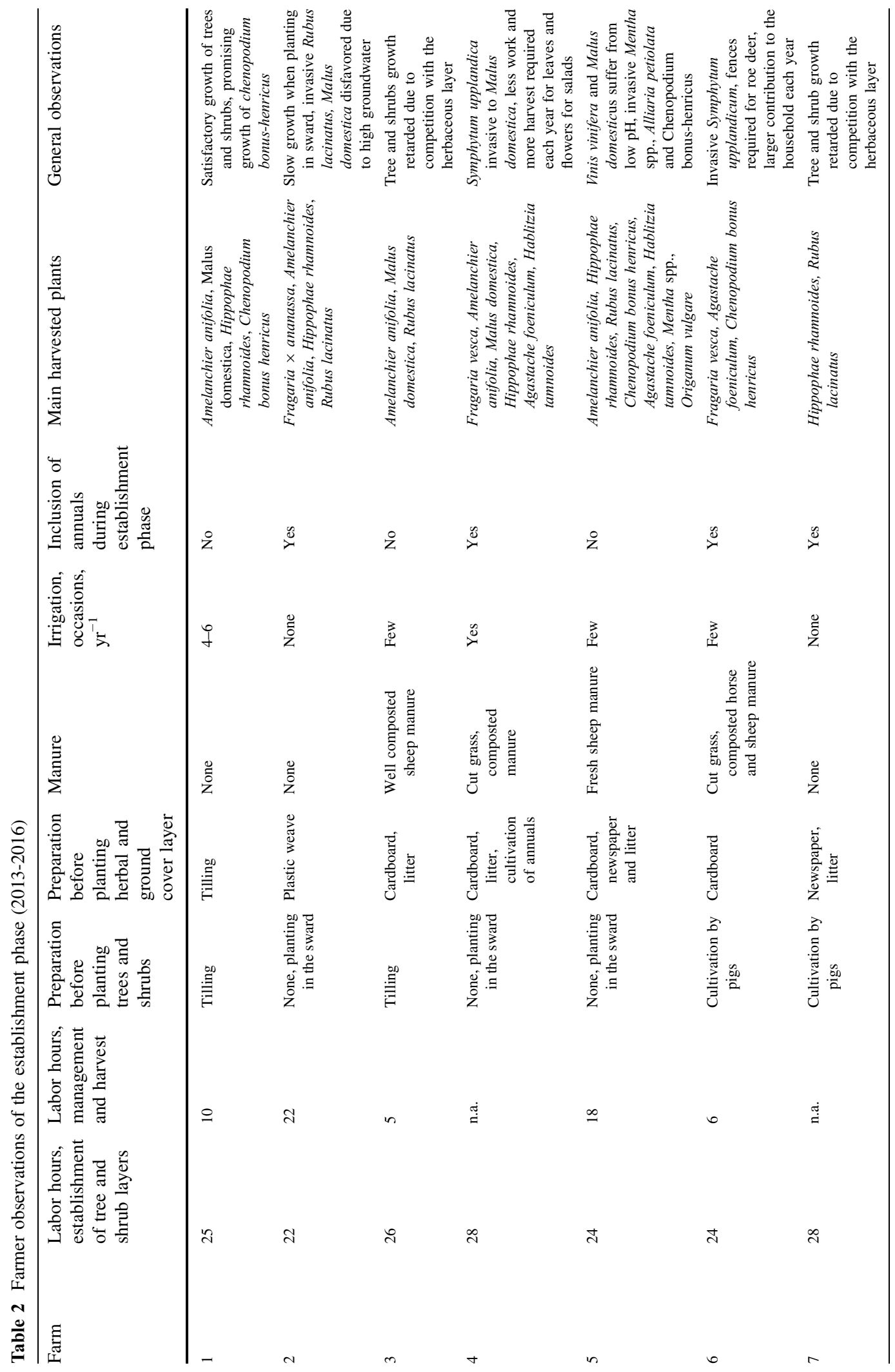




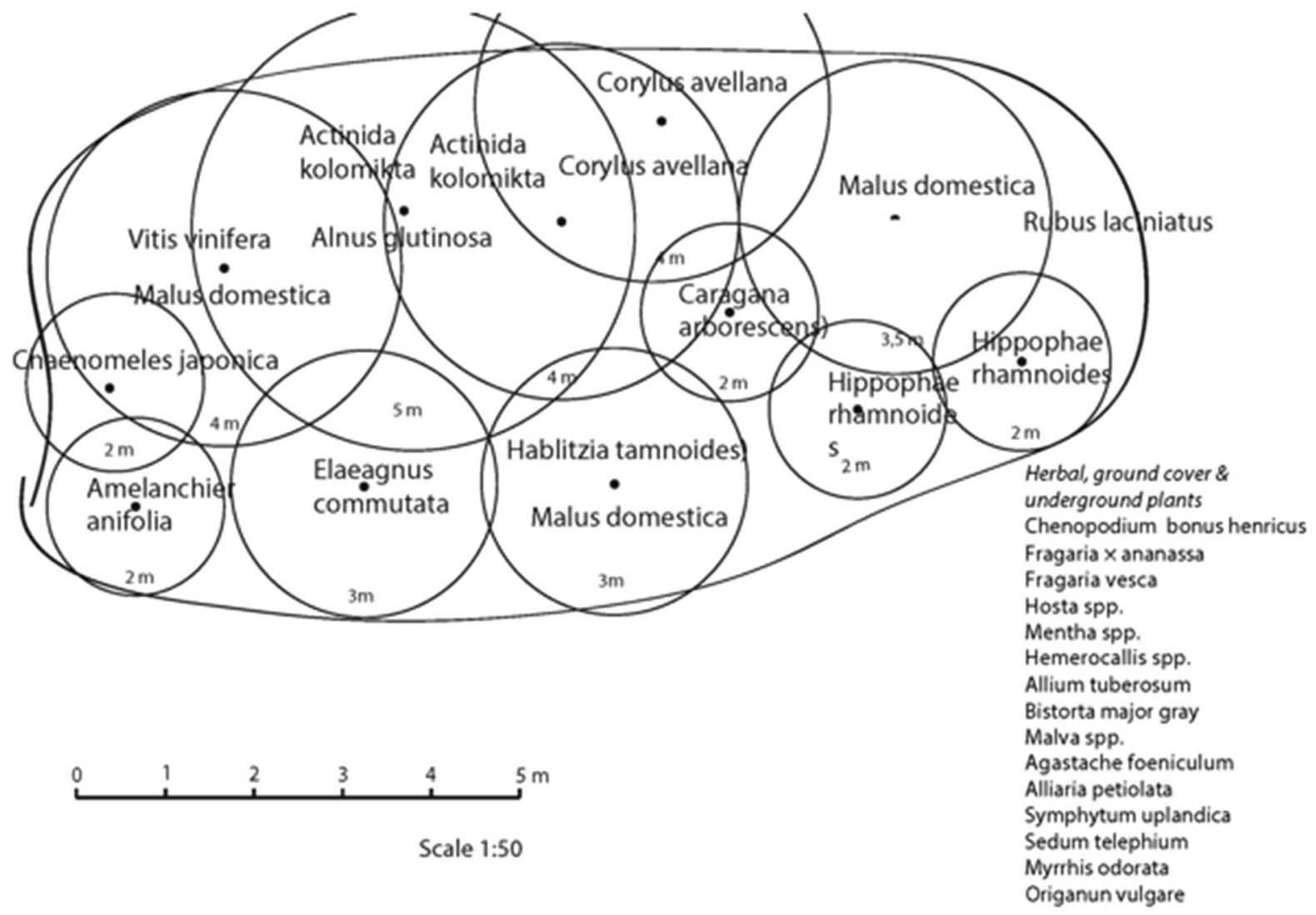

Fig. 2 Edible forest garden designed by the PAR group to study such systems as an approach for food production. Trees, shrubs and climbers are included in the scheme. All intended herbal, ground cover and underground plants are listed to the right

nutrient analysis of the seeds from good king Henry indicated that when cooked and the water was poured off, the content of bad-tasting oleanolic acid was low $(<0.03 \%)$. If the seeds of good king Henry are shown to have edible value, the group stressed that it might also be appropriate to grow in monoculture in larger areas, facilitating harvest and contributing to turning agricultural production toward perennial crops.

\section{Ground cover plants and creepers}

At some sites where this layer did not develop well, it lacked space in terms of soil and light due to the strength of the herbaceous layer. The careful selection of plants for both layers was emphasized to ensure adequate interactions among species and an optimal combination of required edible products. However, at the edges, plants such as strawberry
$($ Fragaria $\times$ ananassa $)$ and wild strawberry (Fragaria vesca) thrived.

\section{Climbers}

Blackberries (e.g., Rubus laciniatus and Rubus fruticosus) and vines (Vitis vinifera) were included at the research sites. Both plants required support on which to climb before the trees were well established, and the blackberries required intensive pruning in some gardens. Caucasian spinach (Hablitzia tamnoides) was a climber that caught interest. This climber was found to grow fast and provide tasty leaves for salads throughout the growing season. Another climber that was included was the tasty and vitamin C-rich arctic kiwi (Actinidia kolomikta). However, the establishment of the plants was found to be somewhat difficult at most sites. 


\section{Underground layer}

In the layer with perennial edible roots and tubers, the possible choices were found to be restricted. The wild alpine bistort (Bistorta vivipara Gray), which is known to have been used as flour during the famine because of its high carbohydrate content (Fält and Källman 1988), was included, but tubers were not used as plants were too small. The culinary values are largely unproven, and breeding efforts might be important for extensive use. The more widely used Jerusalem artichoke (Helianthus tuberosus), which some growers added at the back edge to act as a "wall" and windbreaker, quickly provided acceptable produce where it thrived.

Management regimes, development

of the gardens and working requirements

in relation to outcomes

The gardens developed differently not only because of different groundwater table, nutrient levels and differences in climate conditions but also because of accessibility and time allocation differences. The differences range from fully developed gardens to those heavily affected by wildlife, as well as changes in the herbal composition to less-diverse solutions. The more frequent the visits and the greater the time spent, the more complex the development and the higher the increase in insects, such as butterflies. A reason for this was that visits nearly always included caretaking, such as pruning, weeding and watering.

The labor hours required for planting the tree and shrub level in the gardens were similar irrespective of the methods used (Table 2), while the hours required for management and harvest differed substantially between the participants. The more hours spent on weeding, manuring and watering, the faster the establishment of the plants. The hours spent in the gardens also reflected their uses. The gardens rapidly yielded leaves and berries; however, harvesting required substantial amounts of time, and the participants tended to harvest at different degrees due to factors such as life situations and distances to the garden.

Factors for success and major problems

in the establishment phase

The success in the establishment of an edible forest garden was found to be largely dependent on the management regime, e.g., the distance between the garden and the residence as well as the labor hours available. The initial soil properties were also important. Low $\mathrm{pH}$ and fluctuating water levels affected the establishment of fruit trees and vines. The initial amounts of organic matter and nutrient levels also affected the growth. At some gardens where additional green and composted manure were applied, this successfully accelerated the establishment and increased the harvests. The landscape attributes, e.g., the presence of vole and other wildlife such as moose and roe deer, heavily affected the plant composition of some gardens. Fences may be used, but the design needs to be adjusted to crops that are less appetizing for wild animals in such areas. One experience shared by the majority of the group was the importance of establishing the tree and shrub layer well before planting the herbaceous layer, which would otherwise hinder the growth of the trees and shrubs. At all gardens, some of the domestic plants, e.g., blackberries, comfrey and mint, became invasive and needed to be suppressed or removed.

\section{Experiences of eating}

To understand the potential of producing food through a forest garden, both food production and consumption experiences were documented. As the gardens are still in the establishment phase, the quantities have not yet been properly assessed, but the benefits provided by the gardens so far were justified by the participants.

The edible forest gardens produced energy, proteins and carbohydrates from the edible leaves, seeds, flowers, berries, fruits and nuts. The participants stated that obtaining fresh and tasty salads from the garden from the early spring to late autumn, a very extended season for these climate zones, was an easy task. It simply required broadening the definition of a salad to include leaves, herbs and flowers. Obtaining the major part of required vitamins and minerals was also perceived to be easy as a result of the diversity of fruits and berries grown.

Hazel was identified as a key species because of the fat content and high energy density in the nuts. Because nuts were of such interest, group members have tried to create areas with benign microclimates to establish uncommon species in the region, such as northern pecan (Carya illinoinensis), heartnut 
(Juglans ailanthifolia), walnut (Juglans regia) and chestnut (Castanea sativa).

\section{Major benefits}

A general conclusion from the PAR group was that the benefits from an edible forest garden are closely related to a thorough analysis of the social and ecological context before the establishment. The relations among the location, what is grown and the beneficiaries are crucial, and there is not a universal design. For example, forest gardens far from the residence of people, as well as gardens that cover larger areas, need to have simpler crop compositions with coherent harvests than ones situated in a home garden. The objectives for creating an edible forest garden will determine the design and crop choices. A garden with the aim of delivering a daily harvest for cooking may contain a diverse design with multiple species, while a forest garden used to produce a commercial harvest needs to focus on fewer highvalue products that are easily managed and harvested.

The major benefits from the complex composition and design of an edible forest garden that were identified in the PAR project were the delivery of a variety of tasty leaves and flowers for salads and tea throughout the cropping season as well as mineral and vitamin-rich berries. The literature reviews also indicate that a $200 \mathrm{~m}^{2}$ edible forest garden with the design of the present project would produce minerals and vitamins in sufficient quantities to cover the needs of one man-year with the exception of vitamin B12 (Bodö 2013). However, the PAR group was reluctant to support the idea that an edible forest garden approach to production would provide the bulk of the energy necessary in human diets in northern temperate climates. Leafy salads, which would constitute a large part of such a diet, contain a high percentage indigestible fiber. Eating the volume that would provide enough energy might, therefore, be a problem. The group concludes that such a diet would be rather tedious.

Furthermore, the gardens were developed as beautiful places that attracted both humans and beneficial insects.

\section{Discussion}

Scaling up edible forest gardens in the present food landscape

There is a rapidly growing interest in edible forest gardens in temperate industrialized countries [e.g., see the review on food forest projects in (Clark and Nicholas 2013)]. Mainly urban and suburban dwellers establish edible forest gardens in their home gardens or on community-owned land.

However, if an edible forest garden system is intended to contribute to the production of more food rather than to self-sufficiency, the scale of the garden needs to increase. Based on the experiences from the sites of the research gardens in the project, the PAR group detailed where and how such systems could be managed and argued that there are locations that are appropriate for edible forest gardens systems in different shapes also on larger farms. Marginal lands and areas as edges between forest, pasture and arable land, were identified as appropriate. Field islets and point or linear elements in pastures or arable lands, were also suggested locations for such systems. The group stated that in such areas, edible forest gardens would favorably combine food production and carbon sequestration as well as harbor the biodiversity crucial for food production in other areas. This approach provides the possibility of increasing the diversity of products and the total production of a farm without reducing the yields of other crops.

Dixon (1994) argued that degraded, substandard soils and marginal lands, which occupy a significant proportion of the land use in temperate areas, may contribute to substantial long-term carbon sequestration if these areas are used for agroforestry. Smith et al. (2012b) also stated that such land use is especially valuable in marginal areas where the intensification of crop production is not a viable option due to the topography, soil or climate. A strategic location in the landscape near a large area of natural habitat or between remnants of forest patches is emphasized by Jose (2012) to be important for the ecological value of the overall agricultural landscape.

Molnar et al. (2013) point at that the characteristics that make marginal land "marginal" can make the land suitable for agroforestry, which, for example, may help improve the soils. However, the experiences in the PAR group show that these 
characteristics also need to guide the plant choices. Common reasons for abandonment, such as low $\mathrm{pH}$ or high groundwater tables, may otherwise negatively affect the establishment if plants that are sensitive to these conditions are included. The group also emphasized that sites require protection from wild animals or a design that comprises species that can tolerate visits from wildlife such as moose, deer and vole.

Challenges, knowledge gaps and development

High diversity and complexity, which are advantageous for the generation of most ecosystem services, were ultimately found to be the main drawbacks for the management of a production system driven by fossil fuel-based technologies. Sixty square meters can be tended by hand; but, the lack of appropriate technology for management was evident at larger scales. However, it is easy to get stuck in the current technology, but the PAR group proposed solutions such as drones and different types of robots that already exist. Still, the group perceived that the main activities had to be done on one's own, by a hired labor force or by customer self-picking, which reduces the competitiveness compared to monocultural land uses in areas where labor costs are high.

The productivity of an agroforestry system depends on the interactions among and within species and with the abiotic environment (Smith et al. 2012a). Theoretically, the three-dimensional vegetation, both above and below ground, of an edible forest garden, as well as plant interactions with the biotic communities in the soil, facilitate the efficient exploration of available niches, which may lead to high productivity (Cannell et al. 1996). On the other hand, an overlap in the resource use of different species could counteract this benefit (Smith et al. 2012b). In northern temperate regions, light, for example, could be a critical resource, and Malézieux (2012) therefore questions whether this form of land use is optimal in temperate climates. Torralba et al. (2016) also observed a general trend of diminishing positive effects of agroforestry with increased precipitation and decreased temperature. Field studies in the PAR group, together with experiences from other practitioners, indicate that designs with shade-tolerant plants, good spacing, and the placement of plants with increasing heights from the south toward the north, as is possible in edge zones, were important means of reducing light competition.

Experiences from the PAR project, which were supported by the findings by Lowell et al. (2017), point to the crucial knowledge gaps concerning potential production as well as the ecological value of edible forest gardens in temperate areas. There is a lack of data on the yields of specific species when they are grown in monoculture as well as regarding the yields of species in intercropping conditions. The possible design combinations are numerous, and the slow establishment makes this research challenging (Ibid). The PAR group anticipated that access to the varieties of plant materials that have high edible values and can be easily harvested is crucial for the development and expansion of edible forest gardens. The group called for structured breeding work to be organized on a regional basis. Lowell et al. (2017) also anticipated that improved tree crop varieties might "boost the overall performance of the system", and Clark and Nicholas (2013) started this work by identifying species that may be suitable due to cold hardiness, drought tolerance and edibility. The group further identified the need for research on the interactions between the forest garden plants and the above and below ground wild biotic community, e.g., biological regulation due to predation, parasitism, symbiosis and allelopathy.

\section{Conclusions}

The group concluded that the forest garden produces abundant fresh products for consumption throughout the growing season and provides minerals and vitamins that are currently imported, including a vast amount and variety of berries rich in minerals and vitamins. Moreover, the group indicated that the forest gardens had become beautiful, harmonious and pedagogic places that they highly appreciated being in. These experiences call for further efforts to identify the possibilities for producing immense amounts of both common and new forms of fruits, nuts, fat-rich seeds and berries from such systems. There is an urgent need to identify species and combinations that work in different types of sites as well as to evaluate the contributions to the generation of ecosystem services from different designs. 
For edible forest garden approaches to play a serious part in the sustainable development of food production in the future, efforts to develop technologies appropriate for managing such diverse and complex systems, as well as for breeding species for high and harvestable yields, have to be substantially expanded.

We can also conclude that for scaling the multistrata production, adaptation of the edible forest garden design is needed to fit the local context and location.

Acknowledgements We would like to pay tribute to the participants making up this project and thank Ekhagastiftelsen for funding.

Open Access This article is distributed under the terms of the Creative Commons Attribution 4.0 International License (http://creativecommons.org/licenses/by/4.0/), which permits unrestricted use, distribution, and reproduction in any medium, provided you give appropriate credit to the original author(s) and the source, provide a link to the Creative Commons license, and indicate if changes were made.

\section{References}

Alam M, Olivier A, Paquette A et al (2014) A general framework for the quantification and valuation of ecosystem services of tree-based intercropping systems. Agroforest Syst 88:679-691

Bardhan S, Jose S, Biswas S et al (2012) Homegarden agroforestry systems: an intermediary for biodiversity conservation in Bangladesh. Agroforest Syst 85:29-34

Bodö L (2013) En skogsträdgårds potential att täcka en människas närings-och energibehov. Bachelor Thesis. School of Science and Technology, Örebro University, Örebro

Cannell MGR, Van Noordwijk M, Ong CK (1996) The central agroforestry hypothesis: the tree must acquire resources that the crop would not otherwise acquire. Agroforest Syst 34:27-31

Clark KH, Nicholas KA (2013) Introducing urban food forestry: a multifunctional approach to increase food security and provide ecosystem services. Landscape Ecol 28:1649-1669

Crawford M (2010) Creating a forest garden Working with nature to grow edible crops. Green Books, Dartington

De Schutter O, Vanloqueren G (2011) The new green revolution: how twenty-first-century science can feed the world. Solutions 2:33-44

den Herder M, Moreno G, Mosquera-Losada MR et al (2016) Current extent and trends of agroforestry in the EU27. Deliverable Report 1.2 for EU FP7 Research Project: AGFORWARD 613520. https://www.agforward.eu/index. php/en/current-extent-and-trends-of-agroforestry-in-the-eu27. html
Dixon RK (1994) Integrated land-use systems: assessment of promising agroforest and alternative land-use practices to enhance carbon conservation and sequestration. Climatic Change 27:71-97

Dupraz C, Burgess P, Gavaland A et al. (2005) The SAFE European Project Silvoarable agroforestry for Europe. SAFE Final Report. Synthesis of the SAFE project (August 2001-January 2005). INRA, Montpellier

EURAF (2015) Agroforestry in Europe. http://www.agroforestry.eu/AgroforestryInEurope. Assessed 5 Dec 2016

Eksvärd K, Björklund J, Danielsson M et al (2016) Mångfunktionella, lokala odlingssystem - Etablering av modern agroforestry i Sverige 2012-2016. Örebro University and Inspire Action Research AB (in Swedish). http://oru. diva-portal.org/smash/get/diva2:1039204/FULLTEXT01. pdf

European Commission (2016) Agroforestry delivers more ecosystem services than conventional land uses. Science for Environment Policy 28 October 2016 Issue 475 http://ec.europa.eu/environment/integration/research/ newsalert/pdf/agroforestry_delivers_more_ecosystem_services_than_conventional_land_use_475na1_en. pdf. Assessed 5 Dec 2016

Fält L, Källman S (1988) Armens handbok i överlevnad. (M7734-472091), Försvarets bok och blankettråd (in Swedish)

Foley A (2011) Can we feed the world \& sustain the planet? Sci Am 305:60-65

Gliessman SR (2014) The ecology of sustainable food systems, 3rd edn. CRC Press Ink, Boca Raton

Herzog F (1998) Streuobst: a traditional agroforestry system as a model for agroforestry development in temperate Europe. Agroforest Syst 42:61-80

Jacke J, Toensmeier E (2006) Edible forest gardens, volume 2: design and practice - ecological design and practice for temperate-climate permaculture. Chelsea Green Publishing Co, White River Junction

Jose S (2009) Agroforestry for ecosystem services and environmental benefits: an overview. Agrofor Syst 76:1-10

Jose S (2012) Agroforestry for conserving and enhancing biodiversity. Agroforest Syst 85:1-8

Kim D-G, Kirschbaum MUF, Beedy TL (2016) Carbon sequestration and net emissions of $\mathrm{CH}_{4}$ and $\mathrm{N}_{2} \mathrm{O}$ under agroforestry: synthesizing available data and suggestions for future studies. Agr Ecosyst Environ 226:65-78

Lagerquist E (2016) Measuring carbon sequestration and soil fertility in Swedish agroforestry systems-a methodological study. Master's Thesis in Biology, Department of Soil and Environment, Swedish University of Agricultural Sciences, Uppsala, p 19

Landreth N, Saito O (2014) An ecosystem services approach to sustainable livelihoods in the homegardens of Kandy, Sri Lanka. Aust Geogr 45:355-373

Lorenz K, Lal R (2014) Soil organic carbon sequestration in agroforestry systems. A rev. Agron Sustain Dev 34:443454

Lowell ST, Dupraz C, Gold M, Jose S, Revord R, Stanek E, Wolz KJ (2017) Temperate agroforestry research: considering multifunctional woody polycultures and the 
design of long-term field trials. Agroforest Syst. https://doi.org/10.1007/s10457-017-0087-4

Malézieux E (2012) Designing cropping systems from nature. Agrin Sustain Dev 32:15-29

Matsson E, Ostwald M, Nissanka SP, Pushpakumara DKNG (2015) Quanitification of carbon stock and tree diversity of homegardens in a dry zone area of Moneragaka district, Sri Lanka. Agroforestr Syst 89:435-445

Mazza G, Cottrell T (2008) Carotenoids and cyanogenic glucosides in Saskatoon berries (Amelanchier alnifolia Nutt.). J Food Compost Anal 21:249-254

McIntyre BD, Herren HR, Wakhungu J, Watson RT (eds) (2009) International assessment of agricultural knowledge, science and technology for development (IAASTD): synthesis report with executive summary: a synthesis of the global and sub-global IAASTD reports. Island Press, Washington DC

Molnar TJ, Kahn PC, Ford TM, Funk CJ, Funk CR (2013) Tree crops, a permanent agriculture: concepts from the past for a sustainable future. Resources 2:457-488

Montagnini F, Nair PKR (2004) Carbon sequestration: an underexploited environmental benefit of agroforestry systems. Agroforest Syst 61:281-295

Mosquera-Losada MR, McAdam JH, Romero-Franco R et al (2009) Definitions and components of agroforestry practices in Europe. In: Rigueiro-Rodríguez AR, McAdam J, Mosquera-Losada MR (eds) Agroforestry in Europe: current status and future prospects. Springer, New York, pp 3-19

Nair PKR (1993) An introduction to agroforestry. Kluwer Academic Publishers and International Centre for Research in Agroforestry, Dordrecht

Nerlich K, Graeff-Hönninger S, Claupein W (2012) Agroforestry in Europe: a review of the disappearance of traditional systems and development of modern agroforestry practices, with emphasis on experiences in Germany. Agroforest Syst. https://doi.org/10.1007/s10457-012-9560-2
Pretty JN, Noble AD, Bossio D, Dixon J et al (2006) Resourceconserving agriculture increases yields in developing countries. Policy analyses. Environ Sci Technol 40:11141119

Pulido MT, Pagaza-Calderón EM, Martínez-Ballesté A et al (2008) Home gardens as an alternative for sustainability: challenges for sustainability and perspectives in Latin America. Current topics in ethnobotany. In: De Albuquerque UP, Ramos MA (eds) Current Topics in Ethnobotany Homgardens in Latin America. Kerala, Research Singpost, pp 1-15

Smith J, Pearce BD, Wolfe MS (2012a) A European perspective for developing modern multifunctional agroforestry systems for sustainable intensification. Renew Agr Food Syst 27:323-332

Smith J, Pearce BD, Wolfe MS (2012b) Reconciling productivity with protection of environment: is temperate agroforestry the answer? Renew Agr Food Syst 28:80-92

Steffen W, Richardson K, Rockström J et al (2015) Planetary boundaries: guiding human development on a changing planet. Science. https://doi.org/10.1126/science.1259855

Torralba M, Fagerholm N, Burgess PJ, Moreno G, Plieninger T (2016) Do European agroforestry systems enhance biodiversity and ecosystem services? a meta-analysis. Agri Ecosyst Environ 230:150-161

Tsonkova P, Böhm C, Quinkenstein A, Freese D (2012) Ecological benefits provided by alley cropping systems for food production of woody biomass in the temperate region: a review. Agrforest Syst 85:133-152

Willeman L, Hart A, Negra C et al (2013) Taking tree based ecosystem approaches to scale. Evidence of drivers and impacts on food security and carbon sequestration. EcoAgriculture Discussion Paper No. 10. EcoAgriculture Partners, Washington DC. www.ecoagriculture.org

Wilson MH, Lovell ST (2016) Agroforestry-The next step in sustainable and resilient agriculture. Sustainability 8:574. https://doi.org/10.3390/su8060574 